Vladimir Njegomir
Dragan Stojic

UDK 339.727.22(497.1)

Preliminary paper

Prethodno priopćenje

\title{
DETERMINANTS OF INSURANCE MARKET ATTRACTIVENESS FOR FOREING INVESTMENTS: THE CASE OF EX-YUGOSLAVIA
}

\begin{abstract}
The aim of this paper is to investigate factors that influence the attractiveness of insurance market for foreign insurers in case of ex-Yugoslavia region. We use country-specific fixed effects models for panel data that covers five countries during the period 2004-2008, allowing each cross-sectional unit to have a different intercept term serving as an unobserved random variable that is potentially correlated with the observed regressors. The research results indicate that the main forces affecting market attractiveness are insurance demand and human capital. These findings provide significant implications for local governments and for both, foreign and domestic insurers.
\end{abstract}

Key words: globalisation, non-life insurance, market attractiveness, ex-Yugoslavia

\section{INTRODUCTION}

Insurance was one of the first industries that become international. For example, even in 1720 British stock insurance companies, The Royal Exchange and The London, had the monopoly status for insurance business in Great Britain and its colonies (Cummins and Venard, 2007). However, globalisation differs from internationalisation. Instead of cooperation between countries that aims to promote national interests, globalisation aims to achieve vision of united, cosmopolitan and integrated world economy. It understands increased connectedness in economic, social, technological, cultural, political and ecological spheres in the world where time and place factors are losing their decisive role, as was anticipated by Hudson Institute some thirty years ago (Servan-Schreiber, 1968). Although the literature shows that the globalisation processes have been ongoing ever since Homo sapiens (e.g. Gills and Thompson, 2006), we argue that the roots of modern globalisation processes are found in economic liberalism principles, according to which economy is driven by "invisible hand" (Smith, 1952), while the term "globalisation" has first appeared in the economic literature in 1983 (Levitt, 1983).

During the last twenty years, globalisation became one of the most important issues for insurance industries across the globe. Deregulation, privatisation and liberalisation have facilitated globalisation of risks and insurance services (see Swiss Re, 2000; Cummins and Venard, 2007). These processes have spread over regional insurance markets too. Since the breakup of former Yugoslavia, regional economies have been transformed. Instead of being centrally planned, they become market-oriented. Although some barriers remain, such as mandatory cessions to local reinsurance companies in Serbia ${ }^{1}$, regional insurance markets have been generally opened to foreign investments. Combined with the privatisation of state

\footnotetext{
** $\mathrm{PhD}$ in insurance, Department of Industrial Engineering and Management, submajor Engineering and Insurance Management, Faculty of Technical Sciences, University of Novi Sad, Business analyst at Q-Sphere Development, Novi Sad, e-mail: njega@eunet.rs

${ }^{* * *} \mathrm{MsC}$ in mathematics, Employed as teaching assistent at Department of Quantitative Methods in Economics, Faculty of Economics Subotica, University of Novi Sad, Novi Sad, e-mail: stojicd@eccf.su.ac.yu
} 
monopolies and deregulation, liberalisation have facilitated foreign insurers' entry and generated more competitive local insurance markets.

Althought local insurance markets are still modestly developed in terms of insurance density $^{2}$ in relation to their western counterparts, insurance premium growth in countries of ex-Yugoslavia have outpaced premium growth in developed economies (see Swiss Re, 2009; Marovic, Njegomir and Maksimovic, 2010). The pace of growth and subsequent possibility for profit generation, the need for servicing their multinational customers and geographical risk spreading have attracted foreign insurers to regional non-life insurance markets. On the other side, local economies have tend to attract foreign companies in order to generate foreing investments inflows, improve competitiveness of local insurance markets and achieve the greater availability and more afordable insurance coverage. Although the study of the importance of market characteristics that influence foreign insurers' participation ${ }^{3}$ is important for local economies as well as for foreign and domestic insurers, to our knowledge, the study on the issue for the ex-Yugoslavia region's countries is non existent.

While factors that affects insurance demand and supply for non-life insurance have been studied extensively (e.g. Outreville, 1990; Browne, Chung and Frees, 2000; Hussels, Ward and Zurbruegg, 2005), studies on the issue of market characteristics that relate to the participation of foreign insurers are generally scarce. Even when they are available (e.g. Ma and Pope, 2003; Outreville, 2008) they are not focused on insurance markets of exYugoslavia region. Thus, the aim of this paper is to investigate factors that influence foreign insurers' participation, or in other words factors that influence the attractiveness of insurance markets in the case of non-life insurance market in the ex-Yugoslavia region. We hypothesise that profitability, liberalisation, insurance demand and human capital positively affect foreign companies entry while market concentration could have either positive or negative affect. Additionally, we assume the existence of synergetic effect created between market concentration and liberalisation.

The findings of this study will be of particular importance to regional policymakers that seek to better understand how they can influence participation of foreing insurers on local non-life insurance markets. The results will be particularly important for governments' decision making regarding policies as weak policies, institutional, infrastructure and trade barriers could restrain the regional economies' ability to take advantages of globalisation. Additionally, the findings will be of interest for foreign insurers that wish to enter or increase their participation on local non-life insurance markets but also for domestic insurers that seek to understand factors that could influence market competitiveness in order to develop their operations in a way that will provide successful competition with new entrants and to start or increase their cross-border presence on regional non-life insurance market.

We apply linear country speciffic fixed effects model for panel data. Panel data encompass 5 countries of the ex-Yugoslavia region for the period 2004-2008. We have chosen fixed effects due to small number of control variables in each of two models for capturing the effects of unobserved variables that are potentially correlated with the observed regressors.

The reminder of this article is organised as follows. The second section reviews the prior literature. The third section presents theoretical framework of the research, and the fourth section presents the data and methodology employed in the analysis. The fifth section encompass presentation of the empirical results, and the sixth section concludes. 


\section{LITERATURE REVIEW}

In the last twenty years, globalisation of economic activities has received great attention in the economic literature. According to the approach of examinations of the issue, all previous studies that examine companies' participation in foreign markets can be generally divided into two categories: those that focus on firm-specific issues of companies entering foreign markets and those that focus on market-specific characteristics that facilitate or hinder foreign companies' presence. For example, the first group of research studies encompass the analyses of international diversification (e.g. Capar and Kotabe, 2003) and firm-specific competences (e.g. Dunning, 1977; Bartlett and Ghoshal, 1989; Rugman and Verbeke, 2004) as motivators for the establishment of foreign market presence. Other studies emphasize the market specific characteristics as key motivators for foreign companies' presence. Variables such as market size, economic growth, geographical and cultural closeness, trade barriers, human capital, government and institutional effectiveness and market competitiveness are used to depict attractiveness of host countries for foreign companies entry (e.g. Wilhelms, 1998; Katrishen and Scordis, 1998; De Melo, 1999). Some studies (e.g. Agarwal and Ramaswami, 1992; Rugman and Verbeke, 2004) indicate that both firm-specific and marketspecific factors jointly influence companies' participation in a specific national market.

Most of the studies on the issue of factors that influence companies' participation in foreign markets related to financial services are found in the banking literature. Perhaps Clarke et al. (2003) give one of the most comprehensive reviews of existing studies related to the banking industry. They reviewed a substantial body of literature for both, approaches that had examined location-specific factors and approaches that had examined bank-specific factors that influence banks' entry into foreign markets. Regarding location-specific factors, they indicate that the degree of economic integration between a foreign bank's home country and the host country, the host country's market opportunities and entry restrictions and other regulations have are found to affect the pattern and timing of banks' entry into foreign markets. In addition to these factors, Soussa (2004) indicates that research studies found that profit opportunity, information costs (proxied by geographic distance and cultural similarities), deregulation and, specific for the U.S., relaxation of restrictions on interstate banking, have influenced banks' entry into foreign markets.

In the insurance literature, qualitative studies that have examined factors affecting insurers' international operations appeared first. Surveying the U.S. property and liability companies, Schroath and Korth (1989) found that knowledge of foreign markets represents a major managerial barrier to foreign market entry. Based on in-depth interviews with insurance executives, Zimmerman (1999) found that although barriers, especially non-tariff, are one of the factors that influence managerial decision on entering foreign markets but become critical factor if they create prohibitive costs or difficulties.

Empirical, quantitative studies on factors that affect companies' presence in foreign markets in the insurance related literature are relatively new. Moshrian (1999) examined cross-border trade and foreign direct investment in insurance services by using a model for British and German foreign direct investments in insurance. The results of this study suggest that in addition to insurance premiums, national income of the host country, bilateral trade, labor and capital costs and economic growth, the expansion of international insurance services complement those in banking. Examining the internationalisation of the U.S. reinsurance industry, Elango (2003) found support for previous studies done for the insurance industry. This study found that U.S. reinsurers export their services to countries with large markets, 
higher income per capita and insurance prices, where exists bilateral trade and firms operate internationally, while cultural distance was found to be insignificant. While examining foreign direct investments in insurance services in the U.S., Moshrain (2004) found that national income, source countries' insurance market size and host countries' financial development facilitates, while the relatively higher wages and higher costs of capital in the host countries restrain foreign direct investments in insurance services. Berry-Stölzle, Hoyt and Wende (2010) examined successful business strategies for insurance companies entering foreign markets for the period 2004-2007 and found that although these strategies vary across countries they generally involve a high growth rate, increased size and more emphasis on life insurance. Additionally, they found that better risk-adjusted performance is associated with lower financial leverage and mutual organisational form. Ma and Pope (2003) empirically examined the importance of foreign market characteristics that have decisive role for the participation of international insurers in the non-life business of industrialised countries for the period 1995-1998. Their research results indicate that market structure is important factor in determining whether international insurers will participate in a given foreign market but when markets are not competitive, removing of trade barriers significantly improve the attractiveness of host countries. Additionally, their results suggest that the state of development of economy in general, measured by the level of gross domestic product, is positively correlated with the involvement of foreign insurers. Outreville (2008) examined the factors that influence the participation of the world's largest insurance companies in some transition and developing countries using data for the year 2003 only. The study results indicate that location-specific factors, namely the size of a market, human capital, and good governance, provide an explication of the internationalization of insurance groups. The study also suggests that cultural distance, regulatory barriers and market competitiveness significantly influence the host country choice by transnational insurance companies.

Although, Berry-Stölzle, Hoyt and Wende (2010) included insurance markets of Croatia and Bosnia and Herzegovina in their examination of company-specific factors that affects foreign insurers participation, neither of the previous studies does not examine location-specific factors for foreign insurers participation in the region of ex-Yugoslavia. Although our research contains results that extend and complement those in existing literature, the main contribution of the research presented in this paper is original. We depart from Ma and Pope (2003) as we use data for countries in transition; in which sense we are close to Outreville (2008), but depart from his study as our examination exploit time series data instead of single year observation.

\section{THEORETICAL BACKGROUND}

We focus our analysis here on factors that determine the attractiveness of a non-life insurance market for foreign insurers' participation. Following similar approach used by $\mathrm{Ma}$ and Pope (2003), we use foreign companies' premiums $(F P)$ in gross written non-life premium per capita, calculated for each national market of ex-Yugoslavia region, as a proxy for market attractiveness. Factors that we use as control variables, which may explain the attractiveness of a market for foreign insurers, include the following: market competitiveness, barriers to entry, human capital, insurance demand, foreign direct investments and market profitability.

The number of insurance companies that compete in the market determines market competitiveness $(M C)$. Many of the previous studies have found that in less competitive markets insurers have ability to benefit from higher prices and higher profits (e.g. Bain, 1951, 
Montgomery, 1985; Chidambaran, Pugel, and Saunders, 1997; Bajtelsmint and Bouzouita, 1998; Ma and Pope, 2003; Pope and Ma, 2008). Although this might suggest that the higher market concentration would attract foreign insurers, we assume that in markets that are more concentrated dominant market players may inhibit open competition. Following previous literature that indicates that Herfindahl-Hirschman Index (Hall and Tideman, 1967) is more comprehensive measure of market concentration than concentration ratio, the measure of market competitiveness we derive from calculation of this index, first used and named after economists Orris C. Herfindahl and Albert O. Hirschman. We calculate the index by summing the squares of the relative market shares held by each company for each national non-life insurance market from ex-Yugoslavia region, according to following formula:

$H H I=\sum_{i=1}^{n}\left(\frac{p_{i}}{P}\right)^{2}$, where $p_{i}$ is company-specific and $P$ is gross market non-life premium.

Barriers to entry $(E B)$ variable relates to the degree of easiness for foreign competitors to enter the market. Most cited barriers to entry related to insurance markets are usually visible through market access difficulties, reciprocity, non-discrimination and transparency issues and national treatment inconsistencies (Skipper and Kwon, 2007). By reviewing literature related to banking Outreville (2008) points out that in addition to trade barriers, factors such as regulatory environment, measured by government effectiveness, and corruption have affected banks' choice of their foreign market participations. To control for the influence of barriers to entry we use Index of Economic Freedom as a most comprehensive measure for numerous factors that might affect insurers to entry foreign markets. Provided by The Heritage Foundation, this index is generated as average of 10 specific indices that are generated from the analysis of 10 components of economic freedom, including business, trade, fiscal, monetary, investment, financial, labor and freedom from corruption, government size and property rights. The variable assesses each national market on a scale of $0-100$, where higher values indicate a more liberalised environment. Following previous studies presented in the literature review section of this paper, we assume that liberalisation positively affects insurers' decision to participate in a foreign market. Thus, we hypothesise positive relation between the barriers to entry variable and market attractiveness. As in more concentrated market dominant insurers may restrain foreign competitors' entry, following Ma and Pope (2003) we include a variable interacting market competitiveness and barriers to entry $(M C E B)^{5}$ to control for their interactive relationship and its impact on market attractiveness.

The level of available expertise and skills or human capital in a given market is considered to be one of the most important determinants for companies' entry to foreign markets in both insurance (e.g. Outreville, 2008) and non insurance related literature (e.g. Noorbakhsh, Paloni and Youssef, 2001; Focarelli and Pozzolo, 2005; Contractor and Mudambi, 2008). We measure human capital at a given national market by human capital index following methodology used by United Nations Conference on Trade and Development (UNCTAD, 2005:113). This methodology uses following three variables with different weights: literacy rate as percent of population has a weight of 1 , secondary school enrolment as percent of age group has a weight of 2 and tertiary school enrolment as percent of age group has a weight of 3 . As the main requirements to start and run the insurance business are adequate capital and suitable expertise (Atkins and Bates, 2008), we hypothesise positive relationship between human capital index $(H C I)$ at a given national market and market attractiveness. 
According to the long established economic thought that founded the law of supply and demand, it is generally accepted that with the increase of demand the supply would increase too. Therefore, we can assume that insurers' entry into a given foreign market might depend on the level of demand for insurance products at that market. The level of income and wealth are considered to be one of the most important factors that influence insurance market demand (e.g. Harrington and Niehaus, 2004; Skipper and Kwon, 2007). Previous studies (e.g. Outreville, 1990; Browne, Chung and Frees, 2000; Hussels, Ward and Zurbruegg, 2005) imply that the larger the GDP the larger demand for non-life insurance would be. Based on these studies we could assume that demand for insurance varies with the level of income in a similar manner in all countries that follow similar development patterns. As a proxy for the insurance demand (ID) we use natural logarithm of GDP per capita. We hypothesise positive relationship between insurance demand and market attractiveness.

Foreign direct investments are found to be one of the most important impetuses for the internationalisation of companies as they seek to maintain relationships with their domicile clients that expanded their business activities to foreign countries (Andersen, 1993). Similar arguments for service firms' expansion to foreign countries are found in both banking (e.g. Sabi, 1988; Brealey and Kaplanis, 1996; Yamori, 1998) and insurance literature (e.g.Moshrain, 1998; Ma and Pope, 2003; Elango, 2003). To control for this effect we use foreign direct investments per capita data $(F D I)$, as these data indicate the presence of foreign companies in a given market. Following previously mentioned studies, we hypothesise positive interaction between the level of foreign direct investments and market attractiveness for foreign insurers.

Based on the fact that the most important motivator for insurers' establishment and operation is achievement of profitable result, we assume that key trigger that affects their decisions to enter foreign markets is opportunity to derive profit streams. Therefore, markets with higher profit margin may be considered as more attractive. Insurer profit is summary result of their underwriting and investment results, where underwriting result depends on the premium income and expenditures for claims and expenses. Based on definition given by Carol (1993), we calculate insurers' profit margin using following equation:

$\Pi / R=$ Profit $/$ Revenue $=($ Premiums - Losses - Expenses + Investments $) /$ Premiums $=1-$ $L R-E R+R O I$,

where $L R$ is loss ratio, $E R$ is expense ratio and $R O I$ is return on investment. Premiums observed are gross written premiums. Our measure of underwriting profitability $(U P R)$ is proxied by $1-L R-E R$. Due to the lack of information on investment activities, instead of real investment results, as a control variable we observe the difference between long-term interest rate and inflation rate (ROI) for each year and national market of the region of ex-Yugoslavia. We hypothesise positive interaction for both underwriting profitability (UPR) and return on investment $(R O I)$ on market attractiveness.

\section{DATA AND METHODOLOGY}

Following the breakup of former socialist country and introduction of market economies in the region, foreign companies showed increased interest for participation on local markets. Fifteen years after there are evident significant differences regarding foreign companies presence at local markets among countries of the region. 
Majority number of companies headquartered in Croatia, Serbia and FYR of Macedonia are with foreign majority ownership. However, in Croatia the situation is complex as the greater share of non-life insurance premium has been collected by companies with predominant domestic capital. As far as Serbia is concerned, the majority of companies were predominantly in domestic ownership untill 2007 when the structure changed abruptly. FYR of Macedonia exhibited relativly steady growth of foreign investors' share. Contrary to the situation explained for the aforementioned countries, majority of companies established in Slovenia and Bosnia and Herzegovina predominantly have domestic ownership of capital.

Analysing trends of foreign investors' participation in non-life insurance companies in regional countries, we assume that increased foreign capital interest in local insurance market will continue with unchecked and most probably with accelerated pace. Trends of increased foreign companies' interest in local non-life insurnace market can be observed from historical changes of foreign companies' premiums presented in Figure 1.

\section{Figure 1.}

Historical changes of foreign companies' premiums per capita in ex-Yugoslvia region during period 2004-2008

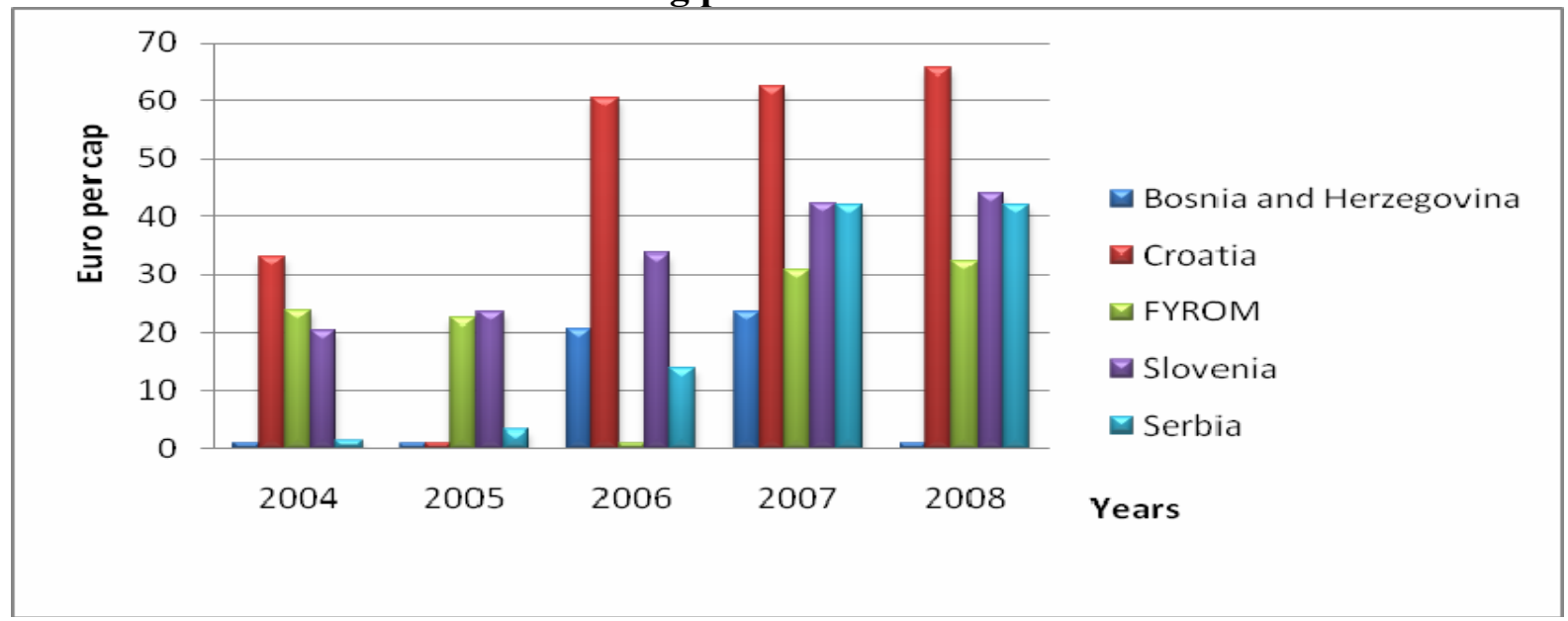

Source: authors' calculations

Note: All monetary values have been denominated to end of 2008 euro value

As it can be seen from the Figure 1, foreign companies' premiums per capita have marked upward tendencies during the period 2004-2008. It is evident that the largest foreign companies premium has Croatian insurance market. Also, it is evident that there is present potential saturation of foreign capital participation as almost marginal changes are present in 2007 and 2008. The changes of foreign companies' premium in Serbia has shown rapid growth in 2007 because of the privatisation of second leading insurance company DDOR Novi Sad. Steady growth of foreign companies' premium has been marked in Slovenia and FYR of Macedonia. Finally, as the availability of data for Bosnia and Herzegovina is limited to 2006 and 2007 the time series was too short to predict either upward or downward trend with high accuracy. However, we assume that the foreign insurance premium in Bosnia and Herzegovina would follow the same patern as in the rest of the region, i.e. exibit more or less steady growth.

Our empirical research covers data for 5 countries, which formerly were constituent republics of Socialist Federal Republic of Yugoslavia, over the time period 2004-2008. ${ }^{6}$ Number of observations for each country varies between 3 and 5, depending on data 
availability. Descriptive statistics of cross-sectional and time-series data for each variable depicting market attractivness as well as expected sign of relationship are shown in Table 1.

Table 1.

Descriptive Statistics and Expected Signs of Relationship

\begin{tabular}{crrrrrrrr}
\hline Variable & Sign & \multicolumn{1}{c}{ Mean } & \multicolumn{1}{c}{ Median } & Maximum & Minimum & Std. Dev. & Skewness & Kurtosis \\
\hline FP & & 40.42062 & 32.249 & 65.6625 & 1.6262 & 24.19763 & 1.605846 & 4.548969 \\
UPR & + & 0.13053 & 0.1325 & 0.372392 & -0.03913 & 0.116901 & 0.588856 & 3.076657 \\
ROI & + & 0.02441 & 0.019 & 0.0691 & -0.011 & 0.022738 & 0.562948 & 2.848132 \\
EB & + & 57.04 & 56.45 & 61.9 & 53.4 & 3.151084 & 0.250367 & 1.52509 \\
ID & + & 8745.823 & 6916 & 18551.46 & 2461.044 & 6611.28 & 0.436255 & 1.52037 \\
MC & \pm & 0.2021 & 0.2246 & 0.260823 & 0.008723 & 0.074146 & -1.95305 & 5.831317 \\
FDI & + & 383.8691 & 303.08 & 874.2494 & 42.85001 & 250.1678 & 0.676063 & 2.623625 \\
MCEB & \pm & 11.57783 & 12.471 & 15.40749 & 0.474512 & 4.303502 & -1.83789 & 5.624576 \\
HCI & + & 0.60763 & 0.6632 & 0.738333 & 0.421602 & 0.131689 & -0.41624 & 1.441702 \\
\hline
\end{tabular}

Source: authors' calculations

Data used in empirical analysis are obtained from various sources. Gross written premium, loss, expense, written premium for each company and foreign companies' market share data for each market and every year are obtained from individual countries' regulatory bodies and national insurance associations. Inflation rate and GDP data are obtained from European Bank for Research and Development (EBRD) economic statistics and forecasts published for each year in Transition Report. Population data are obtained from individual countries' statistical offices, except for Bosnia and Herzegovina, the only country that hadn't census since 1991, which is outdated, thus we use EBRD's estimates of total population excluding refugees abroad. Adult literacy rate data are obtained from United Nations Development Programme (UNDP) Human Development Reports for various years while gross enrolment ratio data are obtained from United Nations Educational, Scientific and Cultural Organization's (UNESCO) Institute for Statistics. Long term interest rate data are obtained from United Nations Economic Commission for Europe (UNECE) Statistical Division Database. Index of economic freedom data, that depicts barriers to entry, is obtained from The Heritage Foundation. Finaly, exchange rate of national currencies against the euro and foreign direct investment data are obtained from individual countries' central banks. Foreign direct investment data for Slovenia are obtained from UNCTAD's Country Fact Sheets. All monetary values have been denominated to 2008 euro value and adjusted for inflation by authors.

Given the cross-sectional and time-series data, we use country specific fixed effects panel data regression model with common coefficients across all cross-section members of the pool. The general equation to be estimated is:

$$
y_{i t}=\alpha_{i}+\boldsymbol{x}_{i t} \beta+u_{i t}
$$

where $y_{i t}$ is a scalar dependent variable, i.e. profitability, $\boldsymbol{x}_{i t}$ is a $K \times 1$ vector of independent variables, $u_{i t}$ is a scalar disturbance term, $I$ indexes country in a cross section, and $t$ indexes time measured in years. Since the error terms $u_{i t}$ are potentially serially correlated and heteroskedastic, we propose an autoregressive process of first order: $u_{i t}=\rho u_{i t-1}+e_{i t}$, where $e_{i t}$ is white noise. Our simplified models incorporate White's consistent covariance matrix (White, 1980), for dealing with heteroskedasticity. 
Model 1 incorporates the impact of macroeconomic environment, in which we observe market profitability, on market attractiveness. Namely, we estimate the equation:

$$
\ln (F P)_{i t}=\alpha_{i}+\beta_{1}(U P R)_{i t}+\beta_{2} \ln (I D)_{i t}+\beta_{3} \ln (F D I)_{i t}+\beta_{4}(R O I)_{i t}+u_{i t}
$$

Model 2 explains market attractiveness through the prism of market competitiveness, entry barriers and their interaction. In addition, we observe the impact of human capital. The equation is given in the sequel:

$$
(F P)_{i t}=\alpha_{i}+\beta_{1}(M C)_{i t}+\beta_{2}(E B)_{i t}+\beta_{3}(M C E B)_{i t}+\beta_{4}(H C I)_{i t}+u_{i t}
$$

\section{EMPIRICAL RESULTS}

The models used in this study have been introduced at the end of previous chapter. In this section, we present original results and interpretations concerning both of the observed models.

Model 1 focuses on market attractiveness when influenced by macroeconomic environment and market profitability. The results of the empirical analysis for Model 1 are presented in Table 2.

Table 2.

Parameter estimates from Model 1

\begin{tabular}{crcrr}
\hline Variable & Coefficient & \multicolumn{1}{c}{ Std. Error } & \multicolumn{1}{c}{ t-Statistic } & \multicolumn{1}{c}{ Prob. } \\
\hline UPR & -4.644796 & 1.727029 & -2.689471 & 0.0227 \\
ROI & 1.725433 & 4.449617 & 0.387771 & 0.7063 \\
FDI & -0.125736 & 0.060524 & -2.077455 & 0.0645 \\
ID & 4.992295 & 0.955275 & 5.226031 & 0.0004 \\
\hline R-squared & 0.940848 & Mean dependent var & 3.252329 \\
Adjusted R-squared & 0.893526 & S.D. dependent var & 0.972985 \\
S.E. of regression & 0.317489 & Sum squared resid & 1.00799 \\
F-statistic & 53.01842 & Durbin-Watson stat & 2.197997 \\
Prob(F-statistic) & 0.000002 & & \\
\hline Note: Dependent & & &
\end{tabular}

Note: Dependent Variable: FP.

Source: authors' calculations

The results suggest that three explanatory variables have significant influence on observed market attractiveness. Our examination finds that return on investment $(R O I)$ has statistically insignificant influence on market attractiveness.

Underwriting profitability $(U P R)$ fluctuates depending on movements in non-life insurance premium and monetary value of losses and expenses. The region is heterogenious regarding general trends of underwriting profitability movements during the period 20042008. While FYR of Macedonia, Slovenia and Bosnia and Herzegovina exhibit moderate growth, Serbia and Croatia exhibit decline. It is rather difficult to make suggestion on the future trends as underwriting profitability depends mainly on claims and expense ratios, which are both hardly predictable.

Underwriting profitability is found to have negative impact on market attractiveness and is significant at 5\% level. This is consistent with previous studies (e.g. Ma and Pope, 2003) although they focused on market attractiveness for OECD countries. This rather 
unexpected sign might be explained by high level of expenses in the structure of underwriting profitability calculation.

Foreign direct investments $(F D I)$ have marked increase in all countries of the region during the period 2004-2007. The region as a whole attracted foreign investors as a market of high potential growth during the times when foreign investors could obtain capital cheaply from their financial institutions. The situation changed during 2008 in all countries of the region except Slovenia, where FDI resumed growing. Moderate decline was witnessed in all other countries except in Bosnia and Herzegovina, which suffered sharp decline of more than $50 \%$ in relation to 2007 . Therefore, it is obvious that financial crisis has hit the investments in the region hard. We assume that when economic crisis ends the volume of FDI will resume growth.

The impact of foreign direct investments is found to be negative and significant at $10 \%$ level. This means that with $1 \%$ increase of FDI premium written by foreign insurers would decrease by $0.12 \%$. The negative sign is unexpected and in contrast to previous studies. Elango (2003) and Moshrain (1999) found positive relationship while Ma and Pope (2003) found insignificant impact. Our result suggests that foreign insurers that enter non-life insurance markets of ex-Yugoslavia region do not necessarily follow their clients. For example, we witnessed FDI decline in Serbia in 2007 yet at the same time Fondiaria Sai (Italian insurer focusing mainly on motor insurance) acquired second largest insurer, hence skyrocketing foreign insurers share from $22 \%$ to $59 \%$.

Insurance demand (ID) as proxied by GDP per capita have marked constant growth in all countries during the observed period. However, the pace of GDP growth has decelerated in 2008 due to financial crisis. As with foreign direct investments, we assume that GDP will resume growth when crisis ends.

Insurance demand is found to have positive and significant influence at $1 \%$. This means that with $1 \%$ increase in insurance demand, premium written by foreign insurers would increase roughly by 5\%. This result is consistent with previous studies that suggest that with the increase of insurance demand increase the market becomes more attractive for foreign insurers' participation.

Model 2 focuses on market attractiveness when influenced by market competitiveness, entry barriers and their interaction and human capital. The results of the empirical analysis for Model 2 are presented in Table 3. 
Table 3.

\begin{tabular}{crrrr} 
& \multicolumn{4}{c}{ Parameter estimates from Model 2 } \\
\hline Variable & Coefficient & Std. Error & t-Statistic & \multicolumn{1}{c}{ Prob. } \\
\hline EB & 34.92526 & 20.01428 & 1.745017 & 0.2231 \\
MC & 10039.93 & 5629.85 & 1.783338 & 0.2165 \\
MCEB & -170.9916 & 96.08352 & -1.779614 & 0.2171 \\
HCI & 297.8919 & 106.4042 & 2.799626 & 0.1074 \\
\hline R-squared & 0.90661 & Mean dependent var & 38.60707 \\
Adjusted R-squared & 0.533048 & S.D. dependent var & 23.7308 \\
S.E. of regression & 16.21618 & Sum squared resid & 525.929 \\
F-statistic & 6.471827 & Durbin-Watson stat & 3.600398 \\
Prob(F-statistic) & 0.136762 & & \\
\hline Note: Depend & &
\end{tabular}

Note: Dependent Variable: FP.

Source: authors' calculations

To control for the influence of barriers to entry (EB) we use Index of Economic Freedom that we observe for the period 2004-2008. In the period of interest we noticed that all countries have showed mild upward tendency. However, being calculated as an average of ten variables it is difficult to predict future values, even though we can assume that index values will not have extreme fluctuations and will move toward improvement as financial crisis have not created institutions crisis, for example. Regarding market concentation, measured by Herfindahl-Hirschman Index, we notice that all regional markets are highly concentrated, with the exception of non-life insurance market of Bosnia and Herzegovina. However, we observe gradual changes towards increased market competitiveness.

First three variables are found to be significant at $10 \%$ level. Entry barriers $(E B)$ and market concentration $(M C)$ have positive impact on market attractiveness, although $\mathrm{MC}$ has stronger impact. Additionally, interaction term $M C E B$ is found to be negative. Treating the $E B$ as an exogenous variable, we find that the increase in $E B$ decreases $M C$. This means that with the increase of liberalisation the market attractiveness decreases. This result is unusual and inconsistent with previous studies that have not focused on countries of ex-Yugoslavia region. However, we found support for our assumption stated in theoretical background that in markets that are more concentrated dominant market players may inhibit open competition.

Human capital index $(H C I)$ measured by the weighted average of adult literacy rate, secondary and tertiary school enrolement shows mild yet steady growth throughout the region during the observed period. As the data for Serbia and Bosnia and Herzegovina are limited we cannot determine the changes of HCI in these countries. We assume that this index will show growth in the future for the region as whole despite the possible negative effects of the financial crisis.

Human capital is found to have positive impact on market attractiveness and is significant at 5\% level. When comparing significance levels of explanatory variables in Model 2 we see that human capital is the major determinant of market attractiveness to foreign insurers. The sign of HCI is in line with previous studies (e.g. Outreville, 2008).

\section{CONCLUSION}

This research study examines factors affecting attractiveness of non-life insurance market of ex-Yugoslavia region for foreign insurers for the period 2004-2008. The region encompasses non-life insurance industries in five countries: Bosnia and Herzegovina, Croatia, 
FYR Macedonia, Serbia and Slovenia. We use two empirical models. Model 1 captures the impact of market profitability, insurance demand and foreign direct investments on market attractiveness. Model 2 focuses on market competitiveness, barriers to entry and human capital when explaining market attractiveness. The research results indicate that the main forces affecting market attractiveness are insurance demand and human capital, both having positive impact.

These results are important for local governments that wish to increase domestic nonlife insurance market competitiveness and capacity, achieve foreign investments inflows and more affordable and available insurance for all. Foreign insurers bring not only additional insurance coverage capacity but also expertise in underwriting, claims handling, loss adjusting, marketing and investments, which could facilitate not only coverage of large risks but also increase in the amount of insurance premium per capita and the volume of invested assets in capital markets. Generally, local governments may use competitive and libaralising policies that could promote or restrain foreign insurers entry. These findings could improve the knowledge of the policymakers of how government policies should be targeted in order to increase or decrease foreign companies' participation.

Having considered the empirical result of our study that growth of GDP and the level of education have positive effect on market attractiveness, governemtns should focus primarily on these two factors. The measures that local governments can use to increase GDP could encompass lowering government expenditures, subsidising activities that lead to improvement in the level of gross capital formation and human capital and lowering administration burden for foreign but also domestic companies in all spheres of the economy. Human capital depends on literacy rate, secondary and tertiary school enrolement. As literacy rate is already at the high level and covered by primary education, which is obligatory in all countries of the region and freely available as well as secondary education, governments should focus on tertiary school enrolement. Measures that governments could use in promoting tertiary level of education may include subsidies to universities and scholarships offering in cooperation with private sector.

Additionally, research results could provide foreign insurance companies an invaluable insight in the characteristics of non-life insurance markets across ex-Yugoslavia region and facilitate their decisions whether to participate or not. The results are useful for both foreign and national insurers to anticipate consequences of possible changes in government policies that will aim to decrease or further increase foreign insurers' presence.

Possible limitation of the research results could be the absence of integral model due to small number of observations. Furthermore, information costs, usually measured by geographic and cultural distance between host and home country, have been omitted due to the lack of relevant data. Further research should focus on the overcoming of the abovementioned limitations.

\section{NOTES}

1. Mandatory cessions will be abolished when Serbia becomes member of the World Trade Organisation. Serbia is in negotiation for WTO membership from 2005.

2. Insurance density is the ratio of annual gross written premium and total population within a country. 
3. Insurers can participate in foreign markets either through cross-border or establishment trade (Skipper and Kwon, 2007). Cross-border trade exists when insured domiciled in one country purchases insurance coverage from insurer that is domiciled in another country. Establishment trade exists when insured and insurer are domiciled in the same country. We limit our discussion here on establishment insurance trade.

4. We apply 0 to insurance markets where HHI is less than 1800 and 1 otherwise.

5. $M C E B$ is obtained by multiplying $M C$ and $E B$.

6. Countries included in our analysis are Bosnia and Herzegovina, Croatia, Former Yugoslav Republic of Macedonia, Slovenia and Serbia. Montenegro was omitted due to lack of relevant available data.

\section{REFERENCES}

Agarwal, J. and Ramaswami, S., (1992), "Choice of Foreign Market Entry Mode: Impact of Ownership, Location and Internalization Factors", Journal of International Business Studies, 23(1):1-27.

Andersen, O., (1993), "On the internationalization process of firms: a critical analysis", Journal of International Business Studies, 24(2):209-231.

Bain, J. S., (1951), "Relation of Profit-Rate to Industry Concentration: American Manufacturing, 1936-1940", Quarterly Journal of Economics, 65(3):293-324.

Bajtelsmit, V. L, Bouzouita, R. (1998), "Market Structure and Performance in Private Passenger Automobile Insurance", Journal of Risk and Insurance, 65(3):503-514.

Bartlett, C. A. and Ghoshal, S., (1989), Managing Across Borders: The Transnational Solution, (Boston: Harvard Business School Press).

Berry-Stölzle, T. R., Hoyt, R. E., and Wende, S., (2010), "Successful business strategies for insurers entering and growing in emerging markets", Geneva Papers on Risk and Insurance - Issues and Practice, forthcoming January issue

Brealey, R. and Kaplanis, E.C., (1996), "The determination of foreign banking location", Journal of International Money and Finance, 15(2):577-597.

Browne, M. J., Chung, J. and Frees, E. W., (2000), "International Property-Liability Insurance Consumption", Journal of Risk and Insurance, 67(1):391-410.

Capar, N. and Kotabe, M., (2003), "The Relationship Between International Diversification and Performance in Services Firms", Journal of International Business Studies, 34(4):345-355.

Carroll, A. M., (1993), "An Empirical Investigation of the Structure and Performance of the Private Workers' Compensation Market”, Journal of Risk and Insurance, 60(2):185207.

Chidambaran, N. K., Pugel, T. A. and Saunders, A., (1997), "An Investigation of the Performance of the U.S. Property-Casualty Insurance Industry", Journal of Risk and Insurance, 64(2):371-381.

Clarke, G. R. G., Cull, R., Martinez Peria M. S. and Sanchez, S. M., (2003), "Foreign Bank Entry: Experience, Implications for Developing Economies, and Agenda for Further Research", The World Bank Research Observer, 18(1):25-59.

Contractor, F. J. and Mudambi, S. M., (2008), "The influence of human capital investment on the exports of services and goods: An analysis of the top 25 services outsourcing countries", Management International Review, 48(4):433-445.

Cummins, J. D. and Venard, B., (2007), Handbook of International Insurance: Between Global Dynamics and Local Contingencies, (New York: Springer Science+Business Media, Inc.). 
De Melo, L. R. Jr., (1999), "Foreign Direct Investment-Led Growth: Evidence from Time Series and Panel Data", Oxford Economic Papers, 51(1):133-151.

Dunning, J. H., (1977), "Trade Location of Economic Activity and the Multinational Enterprise: A Search for the Eclectic Paradigm", in: Ohlin, B, Hesselborn, P-O. and Wijkman P-M. (eds) The International Allocation of Economic Activity : proceedings of a Nobel Symposium held at Stockholm, pp. 398-418 (London: MacMillan).

Elango, B., (2003), "The Effects of Host Country Factors on the Internationalization of the U.S. Reinsurance Industry", Journal of Insurance Issues, 26(2):93-113.

Focarelli, D and Pozzolo, A. F., (2005), "Where do Banks Expand Abroad? An Empirical Analysis", Journal of Business, 78(6):2435-2464.

Gills, B. K. and Thompson, W. R., (2006), Globalization and global history, (New York: Routledge).

Hall, M. and Tideman, N., (1967), "Measures of concentration", Journal of Statistical Association, 62(317):162-168.

Harrington, S. E. and Niehaus, G. R., (2004), Risk Management and Insurance, (New York: The McGraw-Hill Companies, Inc.).

Horizontal Merger Guideliness, (1997), U.S. Department of Justice and the Federal Trade Commission, http://www.justice.gov/atr/public/guidelines/horiz book/15.html (accessed on 20 October, 2009).

Hussels, S., Ward, D. and Zurbruegg, R., (2005), "Stimulating the Demand for Insurance", Risk Management and Insurance Review, 8(2):257-278.

Katrishen, F. A. and Scordis, N. A., (1998), "Economies of Scale in Services: A Study of Multinational Insurers", Journal of International Business Studies, 29(2):305-324.

Levitt, T., (1983), "The Globalization of Markets", Harvard Business Review, 61(3):92-102.

Ma, Y-L. and Pope, N, (2003), "Determinants of International Insurers' Participation in Foreign Non-life Markets", Journal of Risk and Insurance, 70(2):235-248.

Marovic, B., Njegomir, V. and Maksimovic, R., (2010), "The Implications of the Financial Crisis to the Insurance Industry - Global and Regional Perspective", Economic Research, 23(2) (accepted for publication).

Montgomery, C. A., (1985), "Product-Market Diversification and Market Power", Academy of Management Journal, 28(4):789-798.

Moshrian, F., (1999), "Sources of Growth in International Insurance Services", Journal of Multinational Financial Management, 9(2):177-194.

Moshrian, F., (2004), "International Investment in Insurance Services in the US", Journal of Multinational Financial Management, 14(3):249-260

Noorbakhsh, F., Paloni, A. and Youssef, A., (2001), "Human Capital and FDI Inflows to Developing Countries: New Empirical Evidence", World Development, 29(9):1593-1610.

Outreville, J. F., (1990), "The Economic Significance of Insurance Markets in Developing Countries", Journal of Risk and Insurance, 57(3):487-498.

Outreville, J. F., (2008), "Foreign Affiliates of the Largest Insurance Groups: Location-Specific Advantages", Journal of Risk and Insurance, 75(2):463-491.

Pope, N. and Ma, Y. (2008), "The Market Structure-Performance Relationship in the International Insurance Sector", Journal of Risk and Insurance, 75(4):947-966.

Rugman, A. M. and Verbeke, A., (2004), "A Perspective on Regional and Global Strategies of Multinational Enterprises", Journal of International Business Studies, 35(1):318.

Rugman, A. M. and Verbeke, A., (2004), "A Perspective on Regional and Global Stretegies of Multinational Enterprises", Journal of International Business Studies, 35(1):318. 
Sabi, M., (1988), "An application of the theory of foreign direct investment to multinational banking in LDCs" Journal of International Business Studies, 19(3):433-447.

Schroath, F. and Korth, C., (1989), "Managerial Barriers to the Internationalization of the U.S. Property and Liabilitiy Insurers: Theory and Perspectives", Journal of Risk and Insurance, 56(4):630-648.

Servan-Schreiber, JJ., (1968), Američki izazov, (Zagreb: Epoha).

Skipper, H. D. and Kwon, W. J., (2007), Risk Management and Insurance: Perspectives in a Global Economy, (Oxford: Blackwell Publishing, Ltd).

Smith, A., (1952), Bogatstvo naroda, (Zagreb: Kultura).

Soussa, F., (2004), "A note on banking FDI in emerging markets: literature review and evidence from M\&A data", Bank of England paper, available at http://www.bis.org/publ/cgfs22gb.pdf (accessed on 3 October, 2009).

Swiss Re, (2000), Emerging Markets: The Insurance Industry in the Face of Globalization, Zurich: Sigma No. 7.

Swiss Re, (2009), World insurance in 2008: life premiums fall in the industrialised countries - strong growth in the emerging economies. Zurich: Sigma No. 3.

UNCTAD, (2005), "World Investment Report: Transnational Corporations and the Internationalization of R\&D", United Nations: New York and Geneva, http://www.unctad.org/en/docs/wir2005 en.pdf (accessed on 21 October 2009).

White, H. (1980) "A Heteroskedasticity-Consistent Covariance Matrix Estimator and a Direct Test for Heteroskedasticity." Econometrica, 48(4), pp. 817-838.

Wilhelms, S. K. S., (1998), "Foreign direct investment and its determinants in emerging economies", African Economic Policy, Paper-Discussion Paper, No.9, available at http://pdf.dec.org/pdf docs/Pnacf325.pdf (accessed on 27 September, 2009).

Yamori, N., (1998), "A note on the location choice of multinational banks: the case of Japanese financial institutions", Journal of Banking and Finance, 22(1):109-120.

Zimmerman, A., (1999), "Impacts of services trade barriers: a study of the insurance industry", Journal of Business \& Industrial Marketing, 14(3):211-228.

\title{
ODREDNICE PRIVLAČNOSTI OSIGURAVATELJSKOG TRŽIŠTA ZA STRANA ULAGANJA: SLUČAJ BIVŠE JUGOSLAVIJE
}

\begin{abstract}
SA
Cilj ovog rada je ispitati utjecaj faktora na atraktivnost tržišta neživotnog osiguranja za strane osiguravače u slučaju regiona bivše Jugoslavije. Podaci obuhvataju pet zemalja regiona u periodu 2004-2008. godine. Koristimo metod grupisanih najmanjih kvadrata za panel podatke sa fiksnim efektima i time kontrolišemo potencijalni utjecaj skrivenih promenljivih sa posmatranim nezavisnim promenljivama u regresiji. Rezultati istraživanja ukazuju da ključni faktori koji utiču na atraktivnost tržišta uključuju tražnju za osiguranjem, tržišnu konkurentnost i ljudski kapital. Ovi rezultati pružaju korisne informacije lokalnim vladama kao i osiguravačima, kako domaćim tako i stranim.
\end{abstract}

Ključne reči: globalizacija, neživotno osiguranje, atraktivnost tržišta, ex-Jugoslavija 